\title{
III. 超電導マグネットのAE
}

\section{1. 超電導マグネット開発と $\mathrm{AE}$}

\author{
前田 秀明
}

(株)東芝 総合研究所 神奈川県川崎市川崎区浮島町4-1

(1986年11月12日受理)

\section{Examples of AE from Saperconducting Magnets}

1. AE in Connection with the Development of Superconducting Magnets Hideaki MAEDA

Research \& Development Center, Toshiba Corp., Ukishima, Kawasaki, Kanagawa 210

(Received November 12, 1986)

\section{Synopsis :}

Application of acoustic emission (AE) measurement to the superconducting magnet is reviewed. Four kinds of applications are available at the moment: (a) Simultaneous measurement of $\mathrm{AE}$ and coil voltage, which is used to identify the quench origin. $\quad$ (b) Measurement of $\mathrm{AE}$ count rate during coil charging, appropriate to recognize the general trend of mechanical disturbance occurence in the magnet. (c) Spectrum analysis of an AE signal generated by a vibrator which is suitable for long range diagnosis of the magnet system. (d) Location of electrical breakdown of instrumentation wires. Each of the techniques is briefly reviewed and compared in this paper.

\section{1. まえがき}

超電導コイルを励磁していると, チリチリという音 がクライオスタットの中から聞こえてくることがあ る。音は時に非常に大きくなる事もあり，まれにでは あるが，音が発生した直後にコイルがクエンチするこ ともある。一般にノイズとして見過されてきたこの種 の音に注目し, 組織的な研究が行われるようになった のは1970年代の後半で, 野村ら（電子技術総合研究 所 $)^{1)}$ が, コイルにアコースティック・エミッション (AE) 測定検出用の圧電素子を取付け, 励磁中の $\mathrm{AE}$ 計数を測定したのが最初である。この方法は, その後 の $\mathrm{AE}$ 測定の一つの標準的な手法になっており，LCT ・コイル ${ }^{2)}$, 東北大学ハイブリッド・コイル ${ }^{3)}$, 電総研 パルス・コイル4)などにも応用されている。

野村らの測定は音響発生のマクロな変化を観測する ものであったが，Turowski (Karlsruhe 原子核研究 所 $)^{5)}$ は個々の音響信号に注目し，これをコイル電圧信 号と共にシンクロ・スコープで測定する新しい手法を 開発した。塚本, Iwasa ら（横浜国立大学, MIT) は,この手法によりクエンチ原因の判定, 位置決めが

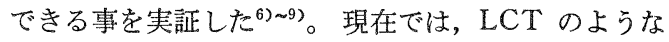
大型コイル2゙から，小型の密巻きコイル ${ }^{10)}$ に至るまで 適用され成果を納めている。

励磁中にコイルから発生する音を観察するという受 身の方法ではなく, AEセンサーを発振器として使い, その結果生じる弾性波を他の AE センサーで受信して スペクトル分析することにより，コイル内部状態を把 握する方法が, 玉田ら (電子技術総合研究所, MIT) により提案されている ${ }^{11)}$ 。これをクエンチ・ディテク ターへ応用する試みもある12)。LCT コイルの絶縁チ エックに $\mathrm{AE}$ 計測が使用され，成功をおさめたことが 最近報告されている

以上のように, 超電導マグネットへ $\mathrm{AE}$ 計測を応用 する方法には, 次の 4 種類がある。

(a) 個々の AE 信号を(電圧信号と共に)測定する,

(b) AE の計数を測定する，

(c) AE センサーを送受信用に使用する，

(d) 絶縁不良場所の標定に利用する。

本解説に続く後の章で, 日本原子力研究所, 電子技 術総合研究所, 東北大学, 成蹊大学, 近畿大学におけ る最近の研究成果の具体的な紹介がある。本解説では

低 温 I 学 


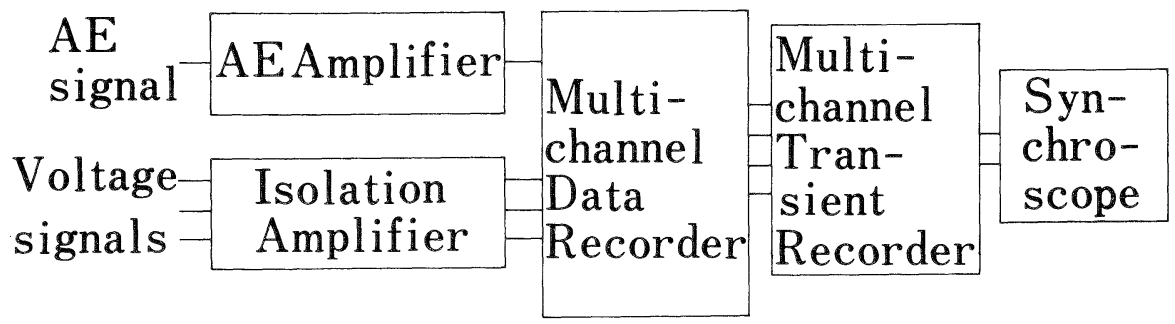

Fig. 1 Block diagram of instrumentation system.

\section{4 方法について概要を比較紹介する。}

\section{2. $\mathrm{AE}$, 電圧信号の同時測定}

計測系の例を Fig. 1 に示した。この方法では, クエ ンチ原因になる機械的擾乱 (conductor motion やエ ポキシの割れ）が作る $\mathrm{AE}$ 信号を正確に捕える必要が ある。クエンチは一過性の現象であるから，これを逃 すことがないように，計測系にはデーター・レコーダ 一を入れることが多い。励磁中にコイル電圧と AE 信 号を記録し，トランジェント・レコーダーで再生して クエンチ原因を検討する方法を取る。

この種の信号例を Fig. 2 亿示す ${ }^{13)}$ 。図は東芝で試 作された超流動へリウム冷却15テスラ・コイルで得ら れた，二つのクエンチ信号である。コイルはボアー33 $\mathrm{mm}$, 外径 $140 \mathrm{~mm}$, 高さ $140 \mathrm{~mm}$ のエポキシ含浸 $\mathrm{Nb}_{3} \mathrm{Sn}$ コイルと, ボアー $150 \mathrm{~mm}$, 外径 $276 \mathrm{~mm}$, 高さ $295 \mathrm{~mm}$ の非含浸 NbTi コイルから成る。Fig. 2 (a), (b) とも上 が $\mathrm{AE}$ 信号，下が $\mathrm{Nb}_{3} \mathrm{Sn}$ コイル電圧信号である。Fig. 2 (a)の場合, クエンチは14.6テスラで発生したが，ノー マル電圧開始直前に大きな電圧パルスが現れている。 $\mathrm{Nb}_{3} \mathrm{Sn}$ コイルは，エポキシ含浸してあるので，エポキ シの割れや㓦離により premature quench が発生す るが。この擾乱により線材が磁界を横切り電圧パルス が発生する。擾乱は $\mathrm{AE}$ を伴うので， AE バーストが 現れる。電圧信号だけではノイズとの判別が付きにく いが、このように $\mathrm{AE}$ バーストと同期していると，機 械的擾乱がクエンチ原因であることが明確になる。

Fig. 2 (b)は，15.1 Tにおけるクエンチ信号である が，電圧パルスも AEも現れず，Fig. 2 (a)とは異った パターンを示す。このような場合，クエンチは熱的な 原因によるものであり，この例では短尺の臨界電流に 達している。 $\mathrm{AC}$ ロスやパワー・リード発熱によるク エンチの場合にも同様な信号パターンが見られる。

非含浸コイルの場合, 擾乱は導体の動き (conductor Vol. 22 No. 1 (1987)

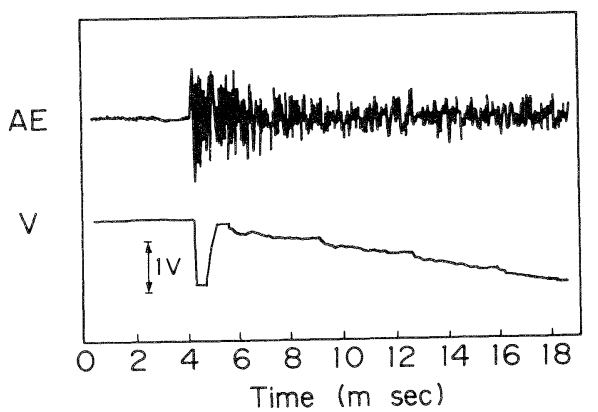

(a)

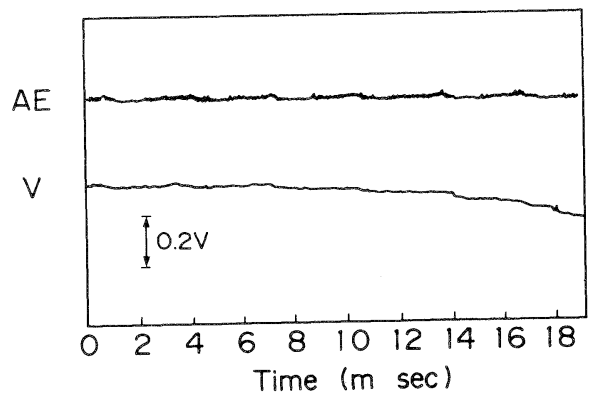

(b)

Fig. $2 \mathrm{AE}$ and voltage signal for a high field magnet $^{133}$. (a) Quenching at $14.6 \mathrm{~T}$ in $\mathrm{He}$ II. (b) Quenching at 15.1T in He II.

motion) であるが，Fig. 2 のように損乱の持続時間は 1 ミリ秒以下で $\mathrm{AE}$ を伴う。大型の LCT コイル2や MFTF コイル ${ }^{14)}$ でも conductor motion の信号が報 告されているが，この場合にも持続時間は同程度であ る。

コイルに取り付けた AEセンサーの数を増し，信号 の時間後れを比較すれば，擾乱の位置決めを行う事が できる ${ }^{9}$ 。実際には，コイルが異種材料の複合体であ るために，この方法で正確な位置決めを行うことは容 易ではない。位置標定のし易い特殊な形状のコイル, 
例えばダイポール・マグネット ${ }^{15)}$, 薄肉ソレノイド ${ }^{16)}$,

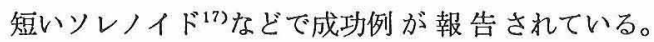

Fig. 3 にこのような例を示した ${ }^{17)}$ 。これは，内径 250 $\mathrm{mm}$, 外径 $314 \mathrm{~mm}$, 高さ $52 \mathrm{~mm}$ の $\mathrm{Nb}_{3} \mathrm{Sn}$ ソレノイド (非含浸) のクエンチ信号である。直径に比べて長さ が短いので, コイルは平面状に近くなり位置標定が行 い易い。Fig. 4のように取り付けた四つのセンサーの $\mathrm{AE}$ 信号の内, $\mathrm{AE} 3$ が一番速く応答している。(a)こ の部分は, 最外ターンに付けた NbTi 線が最も動きや すい場所であること，(b)電磁オシロによる電圧信号測 定ではクエンチは外層の 4 層から発生していることな どから，NbTi 線の動きがクェンチを引き起こしてい ると判定された。この例のように，現時点では位置標 定といっても「大体このあたりである」という程度の ものであり，狭い範囲に場所を決定できるわけではな Wo

Fig. 2 のような電圧信号を更に詳細に検討すると， 擾乱の大きさを定量的に把握する事ができる。コイル の一部が Fig. 5 のように電磁力により動き, 磁束を横 切ると, 動いた部分に

$$
V=B L v
$$

の電圧が発生する。ここで $B$ は磁界，Lは動いた部分 の長手方向の長さ，vは動きの速さである。電圧 $V の$ 值を実測し

\section{$V \times$ 電流}

を電圧パルスについて積分すれば，擾乱のエネルギー

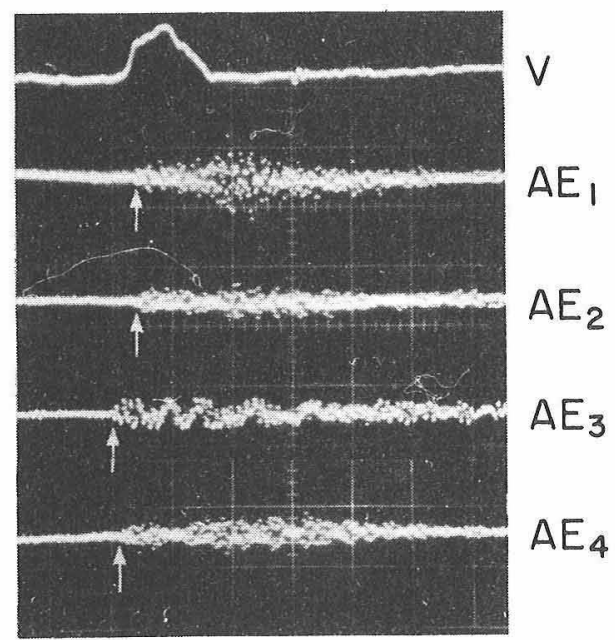

Fig. 3 Four AE signals and coil voltage ${ }^{17)}$. Voltage signal is $500 \mathrm{mV} /$ div. Time scale is $0.5 \mathrm{~ms} /$ div.

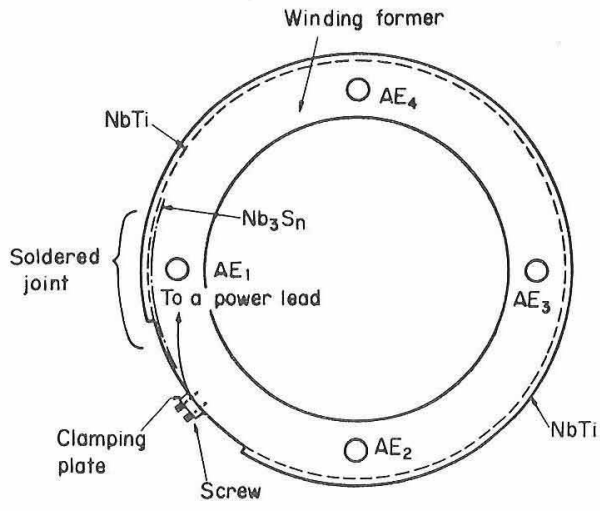

Fig. 4 Four $\mathrm{AE}$ sensor positions on the winding form ${ }^{17)}$.

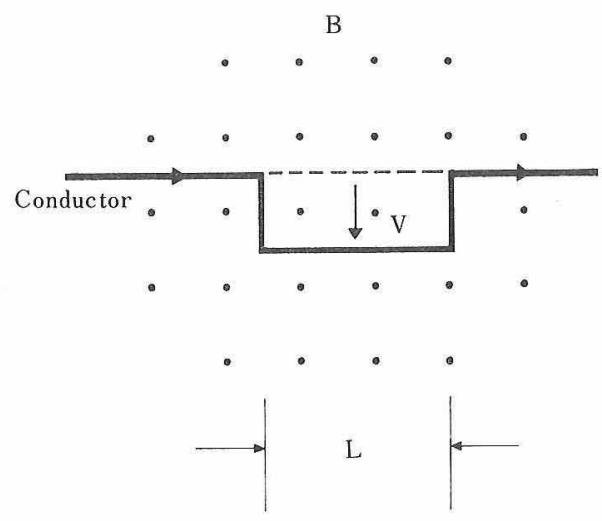

Fig. 5 Deflected conductor segment by the electro-magnetic force.

が求まる。

浦田ら (東芝) ${ }^{100}$ は, 密巻き NbTi コイル（非含浸） の各層に電圧タップを取り付け，上述の電圧 $V$ の值か ら発熱エネルギーを $26 \mathrm{~mJ}$ と求めている。これと, 電 圧パルス終了時点のノーマル電圧からノーマル部の長 さ $120 \mathrm{~mm}$ ，導体が動いた距離 $0.13 \mathrm{~mm}$ を得ている。

コイル・クエンチの原因としては, 以上のような機 械的擾乱や熱的原因の他に，フラックス・ジャンプや ターン閒ショートなどがある。Fig. 2 の15テスラ・コ イルでは, 消磁中に低磁界でFig. 6 のような電圧パル スが発生する ${ }^{13)}$ 。このコイルは $\mathrm{Nb}$ チューブ法という $\mathrm{Nb}_{3} \mathrm{~S}$ 導体を用いている。この導体は直径 90 ミクロン の $\mathrm{Nb}$ チニーブ内壁に数十ミクロンの厚さに $\mathrm{Nb}_{3} \mathrm{Sn}$ を生成するので低磁界でフラックス・ジャンプが発生 
していると推測される。電圧パルスは， $\mathrm{AE}$ を伴わ ず，パルス持続時閒も機珹的損乱に比べて長いという 特徴がある(低磁界なのでコイルはクエンチしない)。 ターン間ショートが発生した場合にも，100ミリ秒程 度の持続時間を持つ電圧パルスが発生する。この場合 にも $\mathrm{AE}$ バーストは現れない。これらの特徽を知れ ば，機械的搷乱と区別することができる。

この種の $\mathrm{AE}$ 測定をコイル励磁試験に導入した経験 に基いて，その利点ををとめると次のようになる。 (イ）コイル励磁中, 電圧信号にスパイクが現れるこ とがある。この種のスパイクは励磁担当者にとっては 不気味な物である。従来のマルチ・ペンによる計測で は，スパイクの原因を判別する事は不可能であった。 $\mathrm{AE}$ 計測の導入により, スパイク発生時点で原因を明 確に判断しながら励磁試験を進めることができるよう になった。（ロ）コイル・クエンチの原因を明らかに できる。コイル特性が上がらない場合には，どのよう な対策を講じるべきがついて正確な指針を得ること ができる。

\section{3. $\mathbb{A E}$ 計数測定}

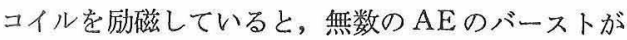
現れる。前節の計測は, この内特定の数個の $\mathrm{AE}$ だけ に注目するものであった。コイル励磁中に発生する $\mathrm{AE}$ 群を森にたとえるなら, 上述の方法は森の中の数 本の木だけに注目している事に対応する。これに対 し，森全体を眺めその広がり，木の分布の様子などを 広い立場から観察してみようといらのが $\mathrm{AE}$ 計数測定 の基本的な考え方である。

この種の測定系では，AE 信号はアンプで増幅され た後、ディスクリミネーターに入れられる。これは，

V

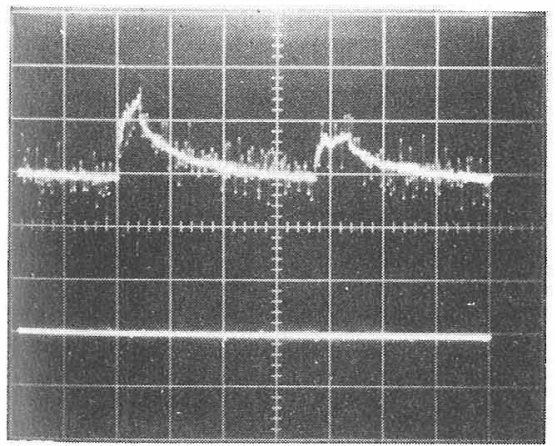

Fig. 6 Voltage and $\mathrm{AE}$ signal for the flux jump ${ }^{13}$. The vertical scale for the voltage signal is $15 \mathrm{mV} /$ div. Time scale is $40 \mathrm{~ms} /$ div. (a)

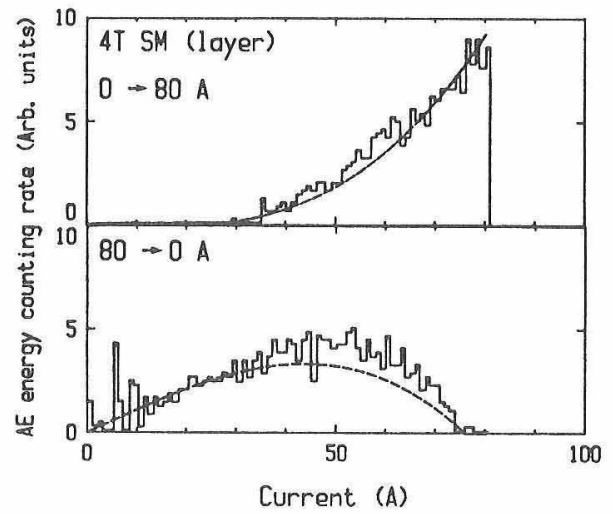

(b)

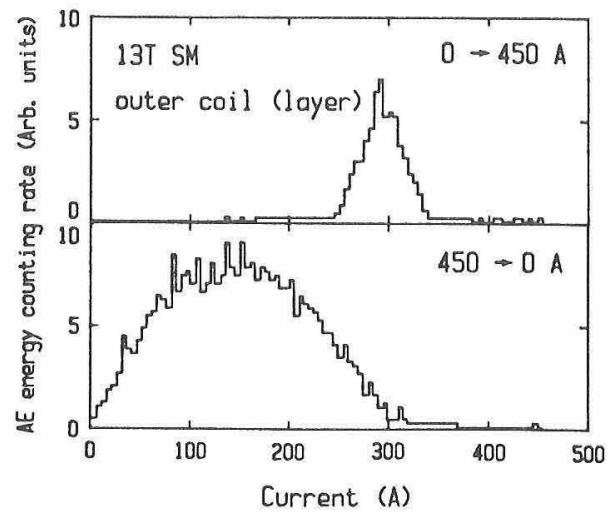

Fig. $7 \mathrm{AE}$ count rate patterns ${ }^{3)}$. (a) Count rate increases with current. (b) Count rate shows a peak in the middle.

振動波形を特定のしきい值（例えば１V）で弁別して パルスに変換するもので（リング・ダウン法）このパ ルス列をカウンターで計数し，コイル電流に対する $\mathrm{AE} の(\mathrm{a})$ 計数率, (b)累積数，(c)エネルギー量の変化な どを表示する。

石川ら (東北大学) $)^{3}$ にれば，コイル電流に対する エネルギー計数率は次の 2 種類のパターンに分けられ る。

（i）コイル励磁中電流と共に単調に計数率が増加 する場合，

(ii）コイル励磁中計数率が途中でピークを持ち， その後減衰する場合,

いずれの場合にも，消磁中には途中でピークを示す。 例を Fig. 7 (a)(b)k示す ${ }^{3)}$ 。Fig. 7 (a)は, 内径 $80 \mathrm{~mm}$, 外径 $166 \mathrm{~mm}$, 高さ $115 \mathrm{~mm}$, Fig. 7(b)冲内径 $202 \mathrm{~mm}$, 外径 $334 \mathrm{~mm}$ ，高さ $299 \mathrm{~mm}$ の NbTi 密巻きコイル（非 
含浸) である。Fig.7 (a)は, 塚本と Iwasa による電 磁力, 弾性力, 摩擦力が働いている場合についての $\mathrm{AE}$ 計数の理論式 ${ }^{18}$ に良く一致している（破線が理論 曲線)。

Fig. 7 (b)のように計数がコイル励磁中にピークを示 すことがあるのは不思議である。浦田ら ${ }^{10)} は$ 同様な測 定を上述の密巻きコイルについて行い，Fig. 8のよう な結果を得ている。図は上から巻き枠内壁に付けた歪 みゲージ信号, $\mathrm{AE}$ の計数率, コイル電流である。コ イル電流が $600 \mathrm{~A}$ 以上になると, ゲージ信号が飽和寸 るが，これは電磁力により巻き線が巻き枠から浮き上 がるためである。浮き上がり開始と同時に，AE の計 数率が急激に滅少している。この減少は, 消磁過程で コイル電流が $600 \mathrm{~A}$ 以下になるまで続き, そこから再 び $\mathrm{AE}$ 計数率が大きくなる。このような振舞いは, 巻 き線部の浮き上がりによ゙り, 音波の伝搬が著しく低下 することに起因している。これはまた，計測されてい る $\mathrm{AE}$ 信号の大部分がコイル内部で発生していること をも示唆している（即ち支持系などからきたノイズは 少ない)。このような情報は， $\mathrm{AE}$ バーストの一つ一 つを眺めていたのでは得られないものであり, 計数率 測定によりはじめて得られるものである。

この種の測定でも，音源の位置標定が可能である。 野村ら ${ }^{4}$ は内径 $400 \mathrm{~mm}$, 外径 $860 \mathrm{~mm}$, 高さ $625 \mathrm{~mm}$ の $3 \mathrm{MJ}$ パルス・マグネットの各ダブル・パンケーキ間 に 4 個づつ $\mathrm{AE}$ のンンーを取り付け，センサーへの 到達時間差から音源の位置を求め CRT 上に表示する 方法を開発している。

近葉ら ${ }^{199}$ (近畿大学) は, コイル励磁中に発生する $\mathrm{AE}$ を FFT 分析する事により, 線材の動きとエポキ シ・クラックを区別し，これを $\mathrm{AE}$ の計数変化と結び 付ける事を試みている。これらの詳細については, 後 の解説に譲る事にする。

\section{4. その他の応用}

以上述べてきたのは，励磁中にコイルから発生する 音を受動的に聞く方法であった。コイルを振動子など で強制的に吒き，その際に生じる音響波を $\mathrm{AE}$ センサ 一で受信してコイル内部の状態を把握しようとする試

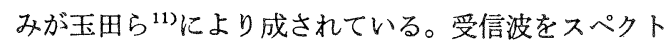
ル分析すると, マグネットの機械的な共振周波数にピ 一クが現れるが，この周波数はコイル内部の応力分布 に依存する。Fig. 9 亿 MIT のハイブリッド・マグネ ットで取られたこの種の信号例を示す ${ }^{11}$ 。コイル電流

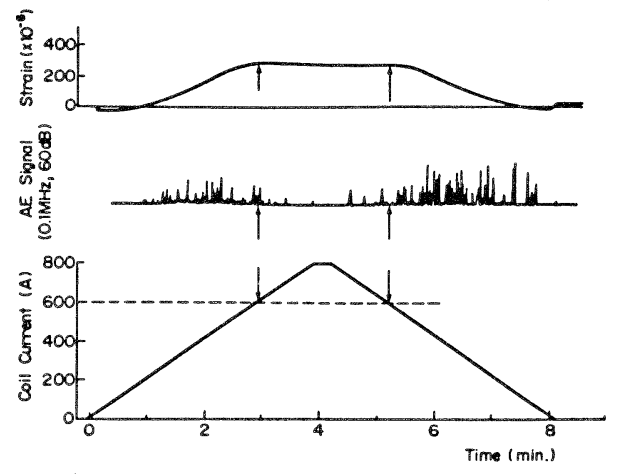

Fig. 8 Strain gauge, AE count rate and coil current for a small solenoid ${ }^{10)}$.

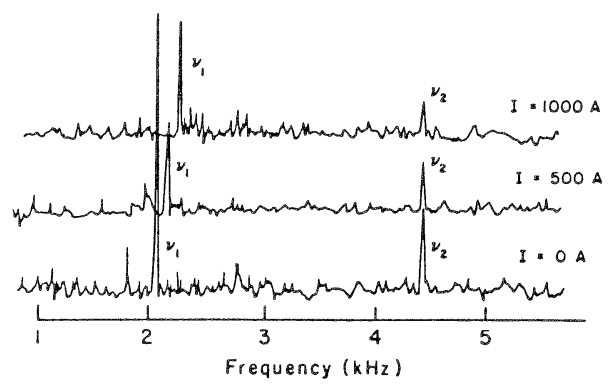

Fig. 9 Traces of the hybrid magnet frequency spectrum at different magnet current settings ${ }^{11}$.

と共に内部応力が増加するので， レ が高周波側にシフ トしている。この種の共振周波数の経時変化を長期に わたって観測することにより，マグネットの内部状態 （例えばクランプ状態, 疲労など）の長期的な監視を 行うことができる。

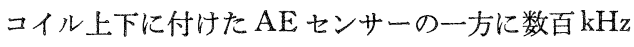
の電圧信号を送り，発生した音波を対向する $\mathrm{AE} ン$ サーで捕えると, コイル内部の温度変化につれて（熱 応力により）共振周波数がシフトするので受信波強度 が変化する。石郷岡ら (成蹊大学, MIT $)^{12)}$ は, この 現象を利用した高感度のクエンチ・ディテクターを提 案している。

日本の LCT コイルは, 当初計測線がクライオスタ ットに対して絶縁不良を起こした。不良場所標定のた めに $\mathrm{AE}$ センサーが使用された2”。これは計測線に高 電圧を加えてスパークを発生させて, 数個のセンサー への到達時間差を測定し, 絶縁不良場所を標定したも のである。この技術は米国 General Dynamics 社の 低温工学 
LCTコイルにも適用され，標定に成功した事を Shen ら (Oak Ridge 国立研究所) が報告している ${ }^{20)}$ 。

\section{5. まとめ}

コイル励磁中に聞こえる音を測定してみようと言う 単純な好奇心に発した $\mathrm{AE}$ 計測技術が，わずかな間に 多岐にわたって広がり，現在ではコイル診断の道具と して欠かせぬ存在になった事がおかかりいたただけたと 思う。昔から聴覚が人間の五感に数えられているよう に，「聞く」事は，物事の認識に久くことができない ものである。AE 計測によって我々が得た「聴覚」を, 単なる診断の具に止めず，さらに有効に活用するなら ば，超電導コイル技術全体を向上させる上でも寄与す るところが多いものと推測される。

\section{参考文献}

1) H. Nomura, K. Takahisa, K. Koyama and T. Sakai: Cryogenics 17 (1977) 471.

2) K. Yoshida, M. Nishi, H. Tsuji., Y. Hattori, S. Shimamoto and O. Tsukamoto: Adv. Cryo. Eng. 31 (1986) 277.

3) 石川 尚, 三浦成人, 中川康昭: 低温工学 21 (1986) 140.

4) 野村睛彦, 立石 裕, 大西利只: 第32回低温工 学研究発表会予稿集 (1984) 78 .

5) P. Turowski: Proc. 6th. International Conf. on Magnet Technology(MT-6), Alpa Press. Bratislava (1978) 648.

6) O. Tsukamoto, M.W. Sinclair, M.F. Steinhoff and Y. Iwasa: Appl. Phys. Lett. 38 (1981) 718.

7) O. Tsukamoto, J.F. Maguire, E.S. Bobrov and Y. Iwasa: Appl. Phys. Lett. 39 (1981)
172.

8) H. Maeda, O. Tsukamoto and Y. Iwasa: Cryogenics 22 (1982) 287.

9) O. Tsukamoto and Y. Iwasa: Appl. Phys. Lett. 40 (1982) 538.

10) M. Urata and H. Maeda: Presented at the Applied Superconductivity Conference in Baltimore (1986).

11) N. Tamada, F. Schauer and Y. Iwasa: Appl. Phys. Lett. 41 (1982) 36.

12) T. Ishigohka, O. Tsukamoto and Y. Iwasa: Appl. Phys. Lett. 43 (1983) 317.

13) H. Maeda, A. Sato, M. Koizumi, M. Urata, N. Aoki, M. Ichihara and E. Suzuki: Adv. Cryo. Eng. 31 (1986) 293.

14) J. Lore, N. Tamada, O. Tsukamoto and Y. Iwasa: Cryogenics 24 (1984) 201.

15) O. Tsukamoto and Y. Iwasa: Stability of superconductors in helium $\mathrm{I}$ and helium II, International Institute of Refregeration (1982) 259.

16) Y. Iwasa, E.S. Bobrov, J. E. C. Williams, O. Tsukamoto, H. Fujita, T. Takagi: Cryogenics 25 (1985) 304 .

17) H. Maeda, M. Koizumi and S. Murase: Cryogenics 23 (1983).

18) O. Tsukamoto and Y. Iwasa: J. Appl. Phys. 54 (1983) 997.

19）近葉實雄，竹尾正勝，山藤 馨，入江冨士男： 第32回低温工学研究発表会 (1984) 74.

20) S.S. Shen, C. T. Wilson and J. N. Luton, Jr. : Adv. Cryo. Eng. 31 (1986) 285. 